JOALL (JOURNAL OF APPLIVI) LINGUIS'IICS ANI) LI'TERA'TURE)

Vol. 6 No. 1, 2021

ISSN (print): 2502-7816; ISSN (online): 2503-524X

Available online at https:/ / ejournal.unib.ac.id/index.php/joall/index doi: http://dx.doi.org/10.33369/joall.v6i1.11462

\title{
FACTORS AFFECTING LISTENING ANXIETY OF SENIOR HIGH SCHOOL STUDENTS IN ENGLISH CLASSROOM
}

\author{
Khairani Ade Guswita1; Sugirin² \\ Applied Linguistics Program, Universitas Negeri Yogyakarta, Indonesia1,2 \\ Corresponding email: khairaniadeguswitalubis@gmail.com
}

\begin{abstract}
In the process of listening, anxiety is a natural response that occurs to the students who can divert the listening process. Thus, the purpose of this study is to find out factors affecting listening anxiety of senior high school students in the English classroom. The method used in this study was mixed method because the data obtained were in the form of qualitative and quantitative data. Participants in this study were 35 senior high school students in 2019-2020 academic year. The instruments used to collect data were questionnaire and interview. The questionnaire contains 14 questions that was adopted from The Foreign Language Listening Anxiety Scale (FLLAS) developed by Kim (2000) that was given to the students and interviews were conducted with an English teacher and three students. The results of this study indicate that there are several factors that cause listening anxiety. The first, the students feel confused and anxious because they are unable to catch the words conveyed by the speaker. The second, the students feel difficult to understand the pronunciation of the speaker. The third, the students feel afraid when the speaker conveyed information too quickly. The fourth, the students feel worried about the limited time in doing the listening task. The fifth, the students feel anxious because they think the other students understand more about the content of the English recording. And the last, the students feel nervous when they do not understand the meaning of each word because they are lack of vocabulary in English. This study is expected to be used by the English teachers to be more aware of the existance of the student's listening anxiety, so they can consider to choose the appropriate listening strategies in teaching at the classroom.
\end{abstract}

Keywords: English classroom; listening anxiety; senior high school student.

\section{INTRODUCTION}

Listening is one of skills in English that is considered difficult but often neglected, when compared to other skills, namely speaking, writing, and reading skills (Richard \& Renandya, 2002). This is because the teachers are 
more likely to prioritize the teaching of speaking, reading and writing skills. This condition is aggravated by society which assume that if someone is able to speak well, this is a reflection that the person is also able to communicate well. One's ability to understand spoken language is one of the important factors in learning a second language because in everyday life, the activity that is often done is listening. Schwartz (as cited in Adnan, 2012) states that adults use half of their communication activities to listen while students receive $90 \%$ of information in the schools from listening to the teachers and from others. Based on the phenomena that occur, one of the factors that affect listening performance is emotion.

In second language learning, emotion as a personality of person is important because it has an impact on learning in the classroom that affects the students' ability to process information accurately. Brown (2007) states that emotions affect learning in the most basic way because emotions are the basis of learning strategies and techniques. Anxiety is one of the emotional conditions that makes listening process difficult. It can divert the students' attention in learning process in the school. It is in line with the affective filter hypothesis proposed by Krashen (1985) which explains that every human being has an affective filter. Something that needs to know is that no one who learns a second language must succeed. One of the causes is comprehensible input that cannot be accepted properly. In addition, Jafari and Hashim (as quoted in Gilakjani \& Sabouri (2016) state that comprehensible inputs are channels for listening. In this context, according to Krashen, motivation, selfconfidence, attitude and anxiety factors will be very important. These four factors are assumed to be effective filters. If the filter is widely open, the input will enter freely. Otherwise, if the filter is narrow or closed, then the input is very difficult to enter or may not enter at all. Furthermore, according to Krashen, this filter will prevent the students from accepting or reproducing language if there is a student who does not like learning English, then the student's filter will be tighter. So if the students dislike or even hate the instructor or the teacher, it will be possible for the students to make mistakes in language because the filters are tighter that it can obstruct the students in language learning.

One of the goals of learning English in senior high school is to develop listening skills in English subject. In Indonesia, the low ability to listen to English is influenced by various factors, among others, the lack of English knowledge, the lack of students' vocabulary, lack of communication practice in daily life, low quality of students assignments, the technique used by the teacher is less precise, and the influence of the students' internal factors themselves (Adnan, 2012). One of the internal factors is anxiety as described above. Foreign language anxiety often occurs especially in the process of learning English. Foreign language listening anxiety is defined as a special 
condition that refers to the tendency that occurs in foreign language listeners in tasks related to listening (Liu 2016; Zhang, 2013). Thus far, a number of scholars have conducted research related to listening anxiety in EFL classroom in other settings, for example in Iran (Dalman, 2016), China (Liu, 2016; Zang, 2013; Fang, 2011), Japan (Kimura, 2008). This influences current study to look into issue within the context of the selected institution because of the limited study conducted in Indonesia. This is indicated by a number of scholars who usually analyze listening anxiety of college student in EFL classroom as their object of study (Agustiana, 2019; Prastiyowati, 2019; Annisa, Adnan, \& Marlina, 2020). Therefore, listening anxiety of senior high school students is still a new study to be observed and it is important to make the students and the teachers more aware of the existence of listening anxiety in the English learning process. Whereas listening skill is not neglected in the English learning process and anxiety is one of the problems that is faced by the students to do the listening task. Thus, this study is important to be conducted to know factors affecting listening anxiety of the senior high school student, especially in SMA Negeri 9 Yogyakarta.

The results of early observation on English learning program in SMA Negeri 9 Yogyakarta show that the students face some difficulties in doing the listening task because of the existence of feeling anxiety during the English listening process. First, the students think listening activity in other languages especially English, is more complicated. Second, the students feel anxious when they try to comprehend the English listening passage. Third, the students avoid and reduce participation because they feel worried about making mistakes when doing the listening task. Finally, the students are still afraid and ashamed to practice the target language because the students think the teacher will scold him and his friends will mock him if he makes a mistake. In addition, as senior high school students who will face the national examination, they are required to be able to do listening tasks in order to obtain good score, especially in the national examination. However, most of them still think that English is a difficult subject in the school. It has an effect on their self-esteem and makes them feel worried in class especially when facing listening tests. In other words, the learning goals will not be achieved properly because of the anxiety experienced by students before conducting learning activities in the classroom. Based on the explanation above, the researchers are interested in conducting research to find out factors affecting listening anxiety of senior high school students in the English classroom.

\section{METHODS}

\section{Participants / Subject / Population and Sample}

The method used in this study was a mixed method. A mixed method research design is a procedure for collecting, analyzing and mixing both 
quantitative and qualitative research. This method was used in a single study to understand research problems (Creswell, 2014). Quantitative method was used to analyze questionnaire given to the students. While qualitative method was used to change the percentage of the students' answer in questionnaire into narratives or words and followed by the results of interview with an English teacher and three students. The participants of this study were 35 students of the twelfth grade at SMA Negeri 9 Yogyakarta, in academic year 2019-2020. The researchers chose the students in the twelfth grade as samples because according to preliminary observation, the twelfth-grade student had done some of listening tasks with hight enough level and they had a preparation to face the national exam in English subject.

\section{Instruments}

In this study, there were two instruments used to collect data, namely questionnaire and interview. Questionnaire is a technique of collecting data through forms that contain questions that are submitted in writing form to someone or a group of people to obtain answers or responses and information needed by the researcher (Mordalis, 2008). This study used a closed questionnaire type. Closed questionnaire is a range of responses that can be chosen by the respondents (Oppenheim, 1992). The questionnaire was adopted from The Foreign Language Listening Anxiety Scale (FLLAS) developed by Kim (2000). This study used 4 scale of Likert scale by eliminating the middle answer (neutral) because it has multiple interpretations, neutral answers do not confirm the respondent's opinion towards agree or disagree, the respondents have a tendency to choose neutral answers (Azwar, 1997). Therefore, the Likert scale used in this study are strongly agree, disagree, strongly agree, and disagree. The questionnaire on listening anxiety contains total of 14 items that evaluate the respondents' perceptions of their listening anxiety.

The second instrument was an interview. The interview results were used to give additional information about the students' anxiety in listening that cannot be obtained from the questionnaire. In this study, the researchers conducted interviews with three students by using random sampling to represent all of the students in a class that become the object of this study and an English teacher who taught in the twelfth grade of senior high school to check whether the data found in the field was in line with what was filled in the questionnaire by the students. The researcher asked questions related to learning English, especially when doing on the listening task.

\section{Data Analysis Procedures}

The data analysis technique used were three stage analysis of mixed method proposed by Ary, Jacobs, \& Sorensen (2009), namely the first stage is data 
reduction. At this stage, data reduction is done by analyzing the results of the questionnaire given to the students who can produce descriptive statistics. Then, the second stage was the data display. In this study, the researchers presented the table form of data percentage in displaying the quantitative data. The third stage was data transformation. At this stage, quantitative data in the form of numbers or statistics are transformed into qualitative data in the form of words or narratives.

\section{FINDINGS}

The findings of the study are discussed based on the problem that has been formulated, namely the factors affecting listening anxiety of senior high school students in the English classroom. Data were obtained by looking at the results of questionnaire that has been given to the students and interview with English teacher and three students. According to Underwood and Kenworthy (1989), there are several aspects that affect students feeling anxious when listening to English recordings which are unable to capture words, speak too fast, lack concentration and lack of English vocabulary.

\section{Unable to Catch the Words}

Listening is one skill that is more challenging than other skills. When listening to English recording, the students often lose words from what the speakers are talking about. This becomes an obstacle for the students to examine the contents of the English recordings that have been played and will influence the students to be able to find the ideas contained in the English recording.

Table: 1 The Result of Student's Answer about Unable to Catch the Word

\begin{tabular}{|c|c|c|c|c|}
\hline Statement & $\begin{array}{c}\text { Strongly } \\
\text { Agree }\end{array}$ & Agree & Disagree & $\begin{array}{l}\text { Strongly } \\
\text { Disagree }\end{array}$ \\
\hline $\begin{array}{l}\text { Feeling confused when listen } \\
\text { to important information in } \\
\text { English recording. }\end{array}$ & $\begin{array}{c}5 \\
(14.3 \%)\end{array}$ & $\begin{array}{c}18 \\
(51.4 \%)\end{array}$ & $\begin{array}{c}7 \\
(20 \%)\end{array}$ & $\begin{array}{c}1 \\
(2.9 \%)\end{array}$ \\
\hline $\begin{array}{l}\text { Feeling afraid when cannot } \\
\text { catch the keyword in English } \\
\text { listening. }\end{array}$ & $\begin{array}{c}6 \\
(17.1 \%)\end{array}$ & $\begin{array}{c}24 \\
(68.6 \%)\end{array}$ & $\begin{array}{c}4 \\
(11.4 \%)\end{array}$ & $\begin{array}{c}1 \\
(2.9 \%)\end{array}$ \\
\hline $\begin{array}{l}\text { Feeling worry when cannot } \\
\text { listen to English recording in } \\
\text { his/her own way. }\end{array}$ & $\begin{array}{c}8 \\
(22.9 \%)\end{array}$ & $\begin{array}{c}50 \\
(57.1 \%)\end{array}$ & $\begin{array}{c}7 \\
(20 \%)\end{array}$ & $\begin{array}{c}1 \\
(2.9 \%)\end{array}$ \\
\hline $\begin{array}{l}\text { Feel annoying when } \\
\text { translating words that cannot } \\
\text { be understood. }\end{array}$ & $\begin{array}{c}7 \\
(20 \%)\end{array}$ & $\begin{array}{c}23 \\
(65.7 \%)\end{array}$ & $\begin{array}{c}15 \\
(14.3 \%)\end{array}$ & $\begin{array}{c}0 \\
(0 \%)\end{array}$ \\
\hline $\begin{array}{l}\text { Cannot catch what the } \\
\text { speaker means. }\end{array}$ & $\begin{array}{c}3 \\
(8.6 \%)\end{array}$ & $\begin{array}{c}24 \\
(68.6 \%)\end{array}$ & $\begin{array}{c}8 \\
(22.9 \%)\end{array}$ & $\begin{array}{c}0 \\
(0 \%)\end{array}$ \\
\hline
\end{tabular}


Based on Table 1, it is proven that the students have difficulty in catching the words and content conveyed in the English recording. In the first statement it was found that as many as 5 students or around $14.3 \%$ choose "strongly agree" and 18 students choose "agree" or around $51.4 \%$. The second statement, there are 6 students or $17.1 \%$ who choose "strongly agree" and the students who choose "agree" are 24 students or about $68.6 \%$. It can be seen that only one person or $2.9 \%$ choose strongly disagree. It explains that they are still feeling afraid because they cannot catch the key words from the English language recordings that they had heard. In the third statement, it was found that students who choose "agree" are 20 people or $57.1 \%$. That is, almost half the number of participants who felt worried when they cannot listen to the recording of English in their own way. This is followed by statements 4 and 5 which show that there are 23 students or $65.75 \%$ who felt annoyed because they cannot translate words that they do not understand and there are 24 people or around $68.6 \%$ who chose "agree". This shows that most students of senior high school students in the twelfth grade at SMA Negeri 9 Yogyakarta cannot catch what is spoken and delivered by the speaker in English recording when they are doing listening tasks. Besides, there were also some students who were still not too confused and anxious when doing listening sections because there were some students who join to English course outside of school. It really helps them to practice their listening skill in the classroom. It is in line with the result of the interview with the student 1, the student felt afraid because she could not catch the word conveyed by the speaker. This makes her missed important information from English recordings. Therefore, the student must focus on the English recording and she usually does a lot of exercises to make her easy to identify the speaker's utterances.

Another factor that caused anxiety in listening to English recording is that the students are still not familiar with English, which is as a foreign language in Indonesia. Table 2 shows students' responses related to the pronunciation of speaker that can obstruct their listening comprehension.

Table: 2 The Results of Students' Answer Related to Pronunciation Speaker

\begin{tabular}{lcccc}
\hline \multicolumn{1}{c}{ Statement } & $\begin{array}{c}\text { Strongly } \\
\text { Agree }\end{array}$ & Agree & Disagree & $\begin{array}{c}\text { Strongly } \\
\text { Disagree }\end{array}$ \\
\hline $\begin{array}{l}\text { Difficult to understand when } \\
\text { the speaker say word }\end{array}$ & 6 & 23 & 6 & 0 \\
$\begin{array}{l}\text { differently than the way of } \\
\text { the student say. }\end{array}$ & $(17.1 \%)$ & $(65.7 \%)$ & $(17.1 \%)$ & $(0 \%)$ \\
\hline
\end{tabular}




\begin{tabular}{lcccc}
\hline \multicolumn{1}{c}{ Statement } & $\begin{array}{c}\text { Strongly } \\
\text { Agree }\end{array}$ & Agree & Disagree & $\begin{array}{c}\text { Strongly } \\
\text { Disagree }\end{array}$ \\
\hline $\begin{array}{l}\text { Difficult to distinguish one } \\
\text { word to another word when }\end{array}$ & $\begin{array}{l}(8.6 \%) \\
\text { listen to English recording. }\end{array}$ & $\begin{array}{c}27 \\
(77.1 \%)\end{array}$ & $\begin{array}{c}5 \\
(14.3 \%)\end{array}$ & $\begin{array}{c}0 \\
(0 \%)\end{array}$ \\
\hline
\end{tabular}

Based on the results of the questionnaire above, on the first statement students who choose "strongly agree" are 23 students or $65.7 \%$ and the students who choose agree are 6 students or $17.1 \%$. Recognizing one word to another word is the most important thing in increasing listening skills. The results of the data explain that the students feel that they understand what the speaker is talking about because the spoken word is different from what the speaker speaks. It has an impact on students' ability to interpret the topics discussed in the English recording. In line with the second statement, there are 27 students or around $77.1 \%$ who choose "agree" and no one choose "strongly disagree". This also confirms the statement that the students are still difficult to distinguish one word to other words when listening to English words. Based on the results of interviews with the teachers, the students are indeed confused to distinguish pronunciation from each word which causes each student to have different interpretations when listening, especially in distinguishing pronunciation from words that are equally pronounced but have different meanings.

\section{Rapid Rate of Speech}

Anxiety in listening can also be caused by the speakers who convey information too quickly. This makes the students unable to follow the speaker's words and obtain the words or meanings conveyed by the speaker. It can be seen from the Table 3 as follows.

Table: 3 The Result of Students' Answer about Rapid Rate of Speech

\begin{tabular}{lcccc}
\hline \multicolumn{1}{c}{ Statement } & $\begin{array}{c}\text { Strongly } \\
\text { Agree }\end{array}$ & Agree & Disagree & $\begin{array}{c}\text { Strongly } \\
\text { Disagree }\end{array}$ \\
\hline $\begin{array}{l}\text { Feeling afraid if the student } \\
\text { might not understand }\end{array}$ & 8 & 20 & 7 & 0 \\
$\begin{array}{l}\text { everything when the speaker } \\
\text { talks quickly. }\end{array}$ & & & & $(0 \%)$ \\
\hline
\end{tabular}

Based on Table 3, there are 20 students who choose "agree" or around $57.1 \%$ and choose "strongly disagree" as many as 8 students or $22.9 \%$ and students who choose "disagree" as many as 7 students or around $20 \%$. This shows that students feel afraid if the speaker speaks quickly. The students also feel difficult to understand the speaker's words. The students feel that many 
words are lost when the speaker speaks very quickly so they cannot follow the speakers. They stated that the words that have been preceded before will disappear. Based on the interview with student 2, he stated that the rapid speech influenced him in doing the listening task. The student felt afraid because the speed of the English recording was too fast so that he could not follow the English recording. Student 3 also stated that in the beginning, she could follow the recording. Since, the speaker talks quickly, she could not follow what the speaker talked about.

This is in line with the limited time that the students have when doing the listening section. The students must be able to control time as well as possible so that they can answer each question from the listening task. This time is very influential on information obtained by students relating to the contents of the recording of the English language. This can be seen from the results of student answers about the limited time in working on listening problems.

Table: 4 The Result of Students' Answer about the Limited Time

\begin{tabular}{|c|c|c|c|c|}
\hline Statement & $\begin{array}{c}\text { Strongly } \\
\text { Agree }\end{array}$ & Agree & Disagree & $\begin{array}{l}\text { Strongly } \\
\text { Disagree }\end{array}$ \\
\hline $\begin{array}{l}\text { Feeling worried when have a } \\
\text { little time to think about what } \\
\text { has been heard in English } \\
\text { recording. }\end{array}$ & $\begin{array}{c}5 \\
(14.3 \%)\end{array}$ & $\begin{array}{c}26 \\
(74.3 \%)\end{array}$ & $\begin{array}{c}4 \\
(11.4 \%)\end{array}$ & $\begin{array}{c}0 \\
(0 \%)\end{array}$ \\
\hline $\begin{array}{l}\text { Feeling nervous if the English } \\
\text { recording is only played once }\end{array}$ & $\begin{array}{c}11 \\
(31.4 \%)\end{array}$ & $\begin{array}{c}17 \\
(48.6 \%)\end{array}$ & $\begin{array}{c}7 \\
(20 \%)\end{array}$ & $\begin{array}{c}0 \\
(0 \%)\end{array}$ \\
\hline $\begin{array}{l}\text { Feeling confused so that make } \\
\text { the student does not } \\
\text { remember what has been } \\
\text { heard in the English } \\
\text { recording. }\end{array}$ & $\begin{array}{c}3 \\
(8.6 \%)\end{array}$ & $\begin{array}{c}24 \\
(68.6 \%)\end{array}$ & $\begin{array}{c}9 \\
(25.7 \%)\end{array}$ & $\begin{array}{c}0 \\
(0 \%)\end{array}$ \\
\hline
\end{tabular}

Table 4 shows the results of answers from the senior high school student questionnaire about the limited time spent when doing on the listening task. The author found that there are 26 students or around $74.3 \%$ who choose "agree", 5 students or around 14.3\% choose "strongly agree", while the students who choose "disagree" are only 4 students or around $11.4 \%$. This shows that some students feel worried when they have little time to think about what has been heard in the English listening task. In the second statement, students who choose "agree" are 17 people or around $48.6 \%$ and the students who choose "disagree" are 11 students or around $31.4 \%$. This explains that some students are nervous when the listening section is only played once. Based on interviews conducted with the teacher, the teacher said 
that students often asked to repeat the recording more than once because they felt that there were some parts that were left behind at the end of the English recording. This is followed by a second statement which shows that there are around 24 students or $68.6 \%$ who choose "agree" and 3 students or $8.6 \%$ who choose "strongly agree". This also ensures that the student cannot remember what he has heard because he feels confused.

\section{Lack of Concentration}

Lack of concentration when listening to English recording makes the students feel anxious because they cannot get what the speaker is talking about. Students often think the other things when listen to the speaker. This can be seen from Table 5 below.

Table: 5 The Results of Students' Answer about the Lack of Vocabulary

\begin{tabular}{|c|c|c|c|c|}
\hline Statement & $\begin{array}{c}\text { Strongly } \\
\text { Agree }\end{array}$ & Agree & Disagree & $\begin{array}{l}\text { Strongly } \\
\text { Disagree }\end{array}$ \\
\hline $\begin{array}{l}\text { Feeling worried that the } \\
\text { student will lose } \\
\text { important idea because } \\
\text { the student does not } \\
\text { focus to the English } \\
\text { recording }\end{array}$ & $\begin{array}{c}4 \\
(11.4 \%)\end{array}$ & $\begin{array}{c}25 \\
(71.4 \%)\end{array}$ & $\begin{array}{c}6 \\
(17.1 \%)\end{array}$ & $\begin{array}{c}0 \\
(0 \%)\end{array}$ \\
\hline $\begin{array}{l}\text { Think that everyone } \\
\text { understand well what } \\
\text { speaker means except } \\
\text { himself. }\end{array}$ & $\begin{array}{c}6 \\
(17.1 \%)\end{array}$ & $\begin{array}{c}17 \\
(48.6 \%)\end{array}$ & $\begin{array}{c}12 \\
(34.3 \%)\end{array}$ & $\begin{array}{c}0 \\
(0 \%)\end{array}$ \\
\hline
\end{tabular}

The first statement in Table 5 shows that there are 25 students or around $71.4 \%$ who choose "agree" and as many as 4 students choose "agree" or around $11.4 \%$. This is followed by the second statement, there are 17 students or $48.6 \%$ who choose "agree" and 6 students or $17.1 \%$ who choose "strongly agree". This shows that the student feels anxious if he loses an important idea from the English recording. They feel difficult to focus when listen to English recording and feel anxious if he only does not know what is being said by the speaker in the English recording. This is very influential with the level of his self-confidence that feels his friends are smarter than him. Based on the interview with student 1 and 3, they felt worried or unconfident when their friends were smarter in doing the listening task. In addition, they realized their friends understood well what the speaker means except themselves. Student 2 also stated that he sometimes felt worried because he could not get the core of the speaker's utterance. He did not focus to the recording because he thought of something else. 


\section{Lack of Vocabulary}

Lack of vocabulary is the most common thing for language learners. Nation (2001) said that vocabulary measurement is one measurement that greatly influences the success of listening to English. This can be seen from Table 6.

Table: 6 The Result of Students' Answer about the Lack of Concentration

\begin{tabular}{lcccc}
\hline \multicolumn{1}{c}{ Statement } & $\begin{array}{c}\text { Strongly } \\
\text { Agree }\end{array}$ & Agree & Disagree & $\begin{array}{c}\text { Strongly } \\
\text { Disagree }\end{array}$ \\
\hline $\begin{array}{l}\text { Feeling nervous and confused } \\
\text { when cannot understand }\end{array}$ & 4 & 23 & 8 & 0 \\
every word in listen to & $(11.4 \%)$ & $(65.7 \%)$ & $(22.9 \%)$ & $(0 \%)$ \\
English recording. & & & & \\
\hline
\end{tabular}

From Table 6 shows that there are 23 students or as many as $65.7 \%$ who choose "agree" and there are 4 people or around 11.4\% who choose "strong disagree", while those who choose "disagree" as many as 8 or around $22.9 \%$. This shows that some students feel nervous and confuse when they do not understand every word that they have heard in the English recording. The students only master a little about English vocabulary so that they cannot get the meaning of what the speaker is talking about. This result is the students do misinterpret the meaning and loss of information relating to the contents of the English recording. Based on the interview with student 1,2,3, the most problems that they face to do listening task is the lack of vocabulary. Student 1 also stated that she can not understand the vocabulary because she seldom heard the words.

\section{DISCUSSION}

After analyzing the data, the next step is discussing the data obtained. The discussion consists of interpretation of the data obtained in this study, relation of the data obtained with the theories from each variable, and the relation or comparison of this study with the previous study. The results of the data were obtained from 35 students of SMA Negeri 9 Yogyakarta.

Based on the data description above, it can be interpreted that the students' anxiety of the twelfth-grade students of SMA Negeri 9 Yogyakarta is quite high. It can be known from the percentage of the student's answer that most of the students chose "Agree" in each statement of the questionnaire.

This study was aimed to find out factors affecting listening anxiety of senior high school students in the English classroom by giving the questionnaire to the students and interview an English teacher. There are several factors that affect the students in the process of listening to audio, namely tension and concern about listening to English and lack of confidence in listening to audio (Kim, 2000). However, this study just focused on the 
tension and concern about listening to English. According to the results, the students' anxiety was mostly caused by the students are unable catch the words conveyed by the speaker, feel difficult to understand the pronunciation of the speaker, feel afraid when the speaker conveying information too quickly, feel worried about the limited time in doing listening task, feel anxious because they think the other student more understand about the contents of the English recording, feel nervous when they do not understand the meaning of each word because they are lack of vocabulary in English.

The findings of this study are in line with Kim's (2000) study which found that delivery speed and unfamiliar pronunciation are the main concerns of foreign language listeners. Another finding is that the students who do not take English training or course show a higher level of anxiety than the students who take English training or course. In addition, the findings of this study support the findings of Kimura (2008) who found two main factors that influence the process of listening comprehension, namely self-focused apprehension and task-focused apprehension. Thus, the findings of this study add to the research findings that second language listeners do indeed experience anxiety listening. Fang (2011) in his study also found the same results and emphasized that listening input characteristics such as difficulty level, nature of speech, and lack of repetition are the main sources of listening anxiety. Furthermore, Fang emphasized that using appropriate listening strategies reduces anxiety levels such as taking notes during the listening process and it can also improve listening comprehension.

In addition, Zhang (2013) in his study also found a similar thing that poor listeners are more anxious in their ability to hear. Listeners feel anxious when listening to foreign language speakers and it can be seen when students quickly forget what they have heard, do not understand what message is meant by the speaker, and ignore the next part while thinking about meaning. Factors that lack of self-improvement will also hamper listening performance such as the students never try to practice listening to English recordings and do listening task to develop their listening skills. It likely because the students have failure experience in listening activities. In other words, the students may have experience failure to identify the content and meaning of English recording so they cannot answer the listening tasks. Therefore, the failure experiences can cause listening anxiety every time they must listen to English recordings in the classroom.

\section{CONCLUSION AND SUGGESTION}

This study aims to find out factors affecting listening anxiety of senior high school students in the English classroom. The results of this study indicate there are several aspects related to student anxiety in listening to English recordings, namely students unable to catch the word containing 5 
statements. From each statement, the students chose "agree" which are about $50 \%$ more. This shows that students feel anxious because they cannot grasp the meaning of the speaker. The second aspect is related to the pronunciation of speakers, there are 2 statements and the results show that most students in the twelfth grade are difficult to listen to English recording because of the different pronunciations that have not been heard by them. The third aspect is the rapid rate of speech. In this aspect the results show that they feel anxious because the speaker is too fast when speaking. This is related to the next aspect, which is about limited time. The results show that the presentation of students who feel worried because of time constraints in doing listening section is quite high. This is also because the recording is played only once or twice. The last aspect is lack of vocabulary. The results of the percentage shows that about $50 \%$ of the students still lack of vocabulary which resulted in their limited understanding of the contents of the English recordings.

The findings of this study indicate that English teachers must have role to encourage the students to practice listening skills. The teachers also need to help the students develop an attitude of confidence and eliminate the anxiety that greatly affects the performance of students in doing the listening task. Further, the teachers also need to consider in choosing the appropriate listening strategies when teaching English in the classroom. In addition, this study also aims to increase awareness to the the students who learn second language about the importance of eliminating anxiety and cultivate selfconfidence to improve listening skills and success in learning English in the classroom.

\section{REFERENCES}

Adnan, A. (2012). Pengajaran menyimak Bahasa Inggris: Masalah dan solusinya. Jurnal Bahasa dan Pembelajaran Bahasa (Lingua Didakti), 6 (1), 19. doi: https://doi.org/10.24036/ld.v6i1.2549

Agustiana, V. (2019). Listening anxiety among Indonesian EFL students. Indonesian EFL Journal, 5 (1), 13-26. doi: https://doi.org/10.25134/ieflj.v5i1.1607

Annisa, S. R., Adnan, A., Marlina, L. (2020). The Relationship between listening anxiety and listening comprehension of English department students in basic listening classes at Universitas Negeri Padang. Journal of English Language Teaching, 9 (3), 510-519. doi: https://doi.org/10.24036/jelt.v9i3.109344

Ary, D., Jacobs, L.C., \& Sorensen, C. (2009). Introduction to research in education. Belmont: Wadsworth, Cengage Learning.

Azwar, S. (1997). Sikap manusia teori dan pengukurannya. Yogyakarta: Pustaka Belajar. 
Brown, H. D. (2007). Principles of language learning and teaching (5 ${ }^{\text {th }}$ ed.). New York: Pearson Education.

Creswell, J. W. (2014). Qualitative, quantitative, and mixed methods approaches. Sage Publication: United States of America.

Dalman, M., R. (2016). The relationship between listening anxiety, listening comprehension strategies, and listening performance among Irian EFL University Student. International Journal of Modern Language Teaching and Learning, 1 (6), 241-252. Retrieved from http://ijmltl.com/fulltext/paper-01122016185800.pdf

Fang, X. (2011). Anxiety in EFL listening comprehension. Theory and Practice in Language Studies, 1(12), 1-3. Retrieved from https://www.researchgate.net/publication/266289695_Anxiety_in_EF L_Listening_Comprehension

Gilakjani, A. P., \& Sabouri, N. B. (2016). Learners' listening comprehension difficulties in English language learning: A literature review. English Language Teaching, 9 (6), 123-133. doi: 10.5539/elt.v9n6p123

Harmer, J. (2007). How to Teach English. Harlow: Pearson Education Limited.

Kim, J. H. (2000). Foreign language listening anxiety: A study of Korean students learning English. University of Texas, Austin.

Kimura, H. (2008). Foreign language listening anxiety: Its dimensionality and group differences. Japan Association for Language TeachingJournal, 30 (2), 173-196. doi: 10.37546/JALTJJ30.2-2

Krashen, S. D. (1985). The input hypothesis: Issues and implications. New York: Longman.

Liu, M. H. (2016). Interrelations between foreign language listening anxiety and strategy use and their predicting effects on test performance of highand low-proficient Chinese University EFL learners. The Asia-Pacific Education Researcher, 25 (4), 647-655. doi: https:/ / doi.org/10.1007/s40299-016-0294-1

Mordalis. (2006). Metode penelitian : Suatu pendekatan proposal. Jakarta: PT Bumi Aksara.

Nation, I. S. (2001). Learning vocabulary in another language. New York: Cambridge University Press.

Oppenheim, A. N. (1992). Questionnaire design, interviewing and attitude measurement. London: Pinter Publisher.

Prastiyowati, S. (2019) Anxiety on students' listening comprehension in university students in Malang. Celtic: A Journal of Culture, English Language Teaching, Literature, and Linguistics, 6(1), 65-77. doi: https://doi.org/10.22219/celtic.v6i1.8758

Richard, J., C. \& Renandya, W., A. (2002). Methodology in language teaching: An anthology of current practice. Cambridge University. 
Factors Affecting Listening Anxiety of Senior High School Students in English Classroom

Underwood, M., \& Kenworthy, J. (1989). Teaching listening. London: Longman.

Zhang, X. (2013). Foreign language listening anxiety and listening performance: conceptualizations and causal relationships. System :

International Journal of Educational Technology and Applied Linguistics, 41 (1), 164-177. doi: https:/ / doi.org/10.1016/j.system.2013.01.004 